\title{
KECENDERUNGAN PEMILIHAN TOPIK DAN ANALISIS KesalahaN PENULISAN JUDUL EsAI MAHAsISWA JURUSAN ILMU HUKUM UNIUERSITAS ISLAM SULTAN AGUNG (SEBUAH KAJIAN MKU BAHASA INDONESIA)
}

\author{
MEILAN ARSANTI \\ Prodi PBSI, FKIP Universitas Islam Sultan Agung \\ meilanarsanti@unissula.ac.id
}

Pertama Diterima: 22 Mei 2017

Bukti Akhir Diterima: 06 Juni 2017

\begin{abstract}
Abstrak
Metode penelitian yang digunakan dalam penelitian ini adalah metode dokumentasi dari tugas-tugas kuliah mahasiswa. Dari hasil penelitian diketahui bahwa mahasiswa Program Ilmu Hukum, Unissula, lebih memilih topik tentang masalah sosial yaitu sebanyak $28,12 \%$ dari 12 topik pilihan yang dipilih oleh 64 mahasiswa. Selebihnya untuk topik tentang politik dan pemerintahan $7,81 \%$, korupsi $15,62 \%$, kesehatan 7,81\%, pendidikan $17,18 \%$, keamanan $1,56 \%$, ekonomi $3,12 \%$, sosial $28,12 \%$, seni dan budaya $0 \%$, hukum $10,93 \%$, teknologi $0 \%$, olahraga $0 \%$, dan lingkungan $7,81 \%$. Dari hasil analisis kesalahan penulisan judul esai yang disajikan dalam diagram batang tersebut diketahui bahwa letak kesalahan penulisan judul pada penulisan huruf kapital sebanyak 10,93\%, penulisan kata sebanyak 4,68\%, penulisan kata-kata yang tergolong sebagai partikel, yaitu konjungsi (kata penghubung) sebanyak 12,50\%, dan penulisan tanda baca sebanyak $3,12 \%$. Pada aspek penulisan huruf miring, kata depan, kata ulang, dan interjeksi (seruan perasaan) sebanyak 0\%. Jumlah total kesalahan terhitung $31,23 \%$ sehingga jumlah penulisan judul yang benar sebanyak $68,77 \%$. Dengan demikian, dapat dikatakan bahwa walaupun mahasiswa Jurusan Ilmu Hukum yang lekat dengan isu-isu masalah hukum, tetapi topik yang cenderung digemari untuk penulisan esai adalah tentang masalah sosial yang terjadi di masyarakat Indonesia. Hal tersebut karena mahasiswa Jurusan Ilmu Hukum semester pertama belum fokus terhadap masalah-masalah hukum. Dapat dikatakan juga bahwa isu-isu sosial yang ada di Indonesia rentan sekali dengan masalah hukum. Dalam menulis judul esai kesalahan terbanyak yang dilakukan oleh mahasiswa Jurusan Ilmu Hukum, Unissula yaitu pada penulisan kata hubung, yaitu kata hubung pada judul esai ditulis dengan huruf kapital, padahal seharusnya ditulis dengan huruf kecil. Selain penulisan kata hubung, kesalahan yang banyak dilakukan adalah penulisan huruf kapital, yaitu huruf yang seharusnya ditulis huruf kapital, tetapi ditulis dengan huruf kecil.
\end{abstract}

Kata Kunci: topik, esai, analisis, judul, bahasa, hukum

\begin{abstract}
Method used in this research was documentation of students' assignments. Result of the research indicated that students of Law Science department in Unissula preferred topics related to social problems, 28.12\% of total 12 topics for 64 students. The rest topics were $7.81 \%$ about politics and government, $15.62 \%$ of corruption, $7.81 \%$ of health, $17.18 \%$ of education, $1.56 \%$ of economics, $28.12 \%$ of social, $0 \%$ of art and culture, $10.93 \%$ of law, $0 \%$ of technology, $0 \%$ of sports, and $7.81 \%$ of environment. Result of error analysis in writing essay title represented in a bar chart indicated that the errors were $10.93 \%$ on capital letter, $4.68 \%$ on
\end{abstract}


words, $12.50 \%$ on words which are included as conjunctions (linking words), and $3.12 \%$ on punctuation. In the aspects of italic words writing, prepositions, repeated words and interjections (feeling exclamations), the errors were 0\%. Total error was about $31.23 \%$ while the correct writing was $68.77 \%$. Thus, it indicated that students of Law Science department, who mostly known to attach to legal issues, preferred to social topics happened in Indonesia. It was because they were freshmen who did not focus on legal issues yet. Social issues are often sensitive to legal issues. In writing essay title, the errors mostly done by students of Law Science department of Unissula were on conjunctions writing, such as using capital letters on conjunctions which should be written with small letters. Besides, the errors mostly happened when the students used capital letters on words which should be written in small letters.

Keywords: topic, essay, analysis, title, language, law

\section{PENDAHULUAN}

Berdasarkan Undang-Undang Republik Indonesia No 12 tahun 2012 tentang Pendidikan Tinggi Pasal 35 Ayat (3) yang berbunyi Kurikulum Perguruan Tinggi sebagaimana yang dimaksud pada ayat (1) wajib memuat mata kuliah Agama, Pancasila, Kewarganegaraan, dan Bahasa Indonesia, maka jelas bahwa pada setiap kurikulum di jurusan atau program pendidikan di Perguruan Tinggi harus ada mata kuliah Bahasa Indonesia. Demikian halnya dengan Fakultas Hukum, Unissula yang menyelenggarakan Mata Kuliah Umum Bahasa Indonesia. Tujuan diberikannya mata kuliah ini yaitu untuk membekali mahasiswa agar memiliki sikap positif terhadap bahasa Indonesia. Adapun tujuan secara khususnya yaitu agar mahasiswa, calon sarjana, terampil menggunakan bahasa Indonesia dengan benar, baik secara tertulis maupun secara lisan.

Sesuai dengan tujuan mata kuliah Bahasa Indonesia maka dalam perkuliahan tersebut mahasiswa dibekali empat keterampilan berbahasa, yaitu mendengar, berbicara, membaca, dan menulis. Masing-masing keterampilan berbahasa tersebut diajarkan dengan metode tertentu oleh dosen pengampunya. Misalnya untuk memberikan bekal mahasiswa agar mempunyai keterampilan menulis maka dosen memberikan tugas untuk menulis esai dengan tema tertentu atau tema bebas. Keterampilan menulis tersebut sangat dibutuhkan, baik selama kuliah mulai dari tugas kuliah hingga ketika menulis skripsi sebagai syarat untuk memperoleh gelar sarjana maupun ketika memasuki dunia kerja.

Salah satu tugas yang diberikan untuk membekali keterampilan menulis yaitu mahasiswa ditugaskan untuk menulis esai. Dikutip dari laman Wikipedia Ensiklopedia Bebas bahwa yang dimaksud esai adalah suatu tulisan yang menggambarkan opini penulis tentang subjek tertentu yang coba dinilainya. Sebuah esai dasar bisa dibagi menjadi tiga bagian, yaitu pendahuluan yang berisi latar belakang informasi yang mengidentifikasi subjek bahasan dan 
pengantar tentang subjek yang akan dinilai oleh si penulis tersebut, isi atau tubuh esai yang menyajikan seluruh informasi tentang subjek, dan penutup yang berisi simpulan dengan menyebutkan kembali ide pokok, ringkasan dari tubuh esai, atau menambahkan beberapa observasi tentang subjek yang dinilai oleh si penulis, sedangkan definisi esai pada Kamus Besar Bahasa Indonesia adalah karangan prosa yang membahas suatu masalah secara sepintas lalu dari sudut pandang pribadi penulisnya. Seirama dengan definisi tersebut, mengenai esai Jassin (1945) memberikan definisi esai bahwa uraian yang membicarakan bermacam ragam, tidak tersusun secara teratur, tetapi seperti dipetik dari bermacam jalan pikiran. Menurutnya dalam esai terlihat keinginan, sikap terhadap soal yang dibicarakan, dan kadang-kadang terhadap kehidupan seluruhnya.

Walapun esai tidak tersusun secara teratur, tetapi ada garis besar yang dapat dipetik dari berbagai macam tulisan yang diutarakan. Selain garis besar tersebut, pada penulisan esai juga terdapat kata kunci, yaitu adanya faktor analisis, interpretasi, dan refleksi. Adapun karakter esai, pada umumnya nonteknis dan nonsistematis dengan karekter dari penulis (unsur subjektivitas) yang menonjol (Rahardi, 2006). Jadi, dalam menulis esai pandangan atau opini penulis sangat terlihat jelas.

Selain definisi-definisi tersebut, definisi lain juga dikemukakan oleh Rampan (2010, hal 168) bahwa esai merupakan bentuk karangan prosa menggunakan bahasa yang memikat perhatian. Pikatan tersebut terutama karena menggunakan beberapa perangkat bahasa yang indah menyimpan gagasan-gagasan berkualitas dan ide-ide jenial. Dalam bahasa Inggris esai disebut essay, sedangkan dalam bahasa Pernacis esai disebut essai. Dalam perkembangannya penulisan esai dikenal dengan esai formal dan esai nonformal.

Berdasarkan paparan definisi esai tersebut maka dapat disimpulkan bahwa esai merupakan jenis karangan bebas yang berisi tentang suatu hal yang sangat dipengaruhi oleh sudut pandang penulisnya dalam menilai suatu masalah. Masalah tersebut misalnya tentang politik, pemerintahan, sosial, hukum, ekonomi, kemamanan, kesehatan, pendidikan, pertanian, lingkungan, oalahraga, dan lain sebagainya. Dengan kata lain, pada tulisan esai berisi opini atau pendapat pribadi penulis yang bersifat subjektif. Selain bersifat subjektif, pada penulisan esai juga bersifat argumentatif yang disertai dengan faktor analisis. Akan tetapi, walaupun bersifat subjektif, argumen yang disampaikan penulis dalam esai harus tetap bersifat logis, dapat dipahami dengan baik oleh pembacanya, dan berdasarkan pada teori atau data dan fakta sesuai kenyataan di lapangan. Dengan demikian, tulisan esai bukan hanya menjadi tulisan imajinasi penulisnya saja, tetapi juga ditulis berdasarkan realita dan data yang ada sehingga dapat dipertanggungjawabkan dari sisi kebenarannya. 
Oleh karena dalam menulis esai penulis boleh menulis tentang topik apa saja, maka dalam perkuliahan Bahasa Indonesia mahasiswa dibolehkan untuk memilih topik sesuai dengan keinginannya. Sebelum menulis esai, mahasiswa diajarkan terlebih dahulu tentang bagaimana cara menulis esai yang baik dan benar mulai dari pemilihan topik, penulisan judul, sistematika, tata bahasa Indonesia, Ejaan Bahasa Indonesia (EBI), hingga proses penyuntingan naskah esai. Setelah mahasiswa dianggap paham selanjutnya proses penulisan esai. Proses penulisan esai dilakukan di kelas dengan pembimbingan dosen pengampu. Jika hasil tulisan esai belum sempurna maka mahasiswa dapat menulis lagi di luar jam perkuliahan dengan waktu yang lebih banyak sehingga diharapkan dapat menulis esai secara maksimal.

Ada beberapa indikator penilaian dalam menulis esai di antaranya yaitu pemilihan topik dan penulisan judul yang tepat. Pemilihan topik ini sangat mempengaruhi kualitas esai. Esai akan banyak dibaca orang bila topiknya menarik, tetapi sebaliknya jika topiknya tidak menarik tentu tidak akan menarik pembaca. Dalam memilih topik esai ada hal-hal yang harus diperhatikan penulis agar esai yang dihasilkan pun baik. Dari berbagai kajian teori maka penulis menyimpulkan hal-hal yang harus diperhatikan dalam memilih topik esai sebagai berikut.

1. Topik harus menarik perhatian penulis.

2. Topik hendaknya dikuasai penulis.

3. Topik hendaknya jangan terlalu baru, jangan terlalu teknis, dan jangan terlalu kontroversial.

4. Topik hendaknya memberikan manfaat bagi pembacanya.

5. Topik hendaknya jangan terlalu luas atau lebih spesifik.

6. Topik hendaknya tidak jauh dari kehidupan masyarakat.

7. Topik yang dipilih memiliki data dan fakta yang objektif.

8. Topik yang dipilih harus diketahui prinsip-prinsip ilmiahnya.

9. Topik yang dipilih memiliki sumber acuan.

10. Topik tidak mengandung unsur SARA.

Setelah memilih topik dengan memperhatikan hal-hal tersebut selanjutnya mahasiswa merumuskan judul. Dalam penulisan judul yang tepat maka mahasiswa harus menyesuaikan dengan aturan baku. Berdasarkan Pedoman Umum Bahasa Indonesia (PUEBI) (2016) aturan baku penulisan judul esai yang meliputi penulisan huruf kapital, kata sambung, dan awalan sebagai berikut. 
1. Huruf kapital digunakan sebagai huruf pertama semua kata.

2. Huruf kecil hanya digunakan untuk kata-kata yang bersifat partikel, kecuali kata ia yang terletak di awal judul.

3. Kata-kata yang tergolong sebagai partikel, yaitu konjungsi (kata penghubung), preposisi (kata depan), dan interjeksi (seruan perasaan) ditulis dengan huruf kecil. Misalnya di, ke, dari, dan, atau, yang, untuk, dengan, dalam, pada, kepada, sebagai, terhadap, jika, maka, tapi, karena, tentang, agar, supaya, hingga, sejak, pun, per, demi, si, meskipun, secara, seperti, ialah, ah, oh, deh, dong, kok.

4. Kata ulang sempurna yang semua unsurnya diawali dengan huruf kapital maka ditulis dengan huruf kapital pada huruf pertama. Jadi, tidak termasuk kata ulang berubah bunyi dan kata ulang berimbuhan.

Melalui penelitian diketahui kecenderungan pemilihan topik sebagai bahan penulisan esai mahasiswa Jurusan Ilmu Hukum, Fakultas Hukum, Unissula. Selain itu, dari hasil penelitian ini juga diketahui tingkat kesalahan penulisan judul esai dari hasil analisis yang dilakukan peneliti yang sekaligus dosen pengampu mata kuliah Bahasa Indonesia di Jurusan Ilmu Hukum, Unissula. Dari hasil penelitian ini dapat dimanfaatkan untuk perbaikan proses perkuliahan Bahasa Indonesia berkaitan dengan keterampilan menulis mahasiswa.

\section{METODE PENELITIAN}

Dalam penelitian ini digunakan rancangan penelitian deskriptif kualitatif untuk memaparkan (1) kecenderungan pemilihan topik pada tulisan esai mahasiswa Jurusan Ilmu Hukum, Unissula, dan (2) analisis kesalahan penulisan judul pada esai mahasiswa Jurusan Ilmu Hukum, Unissula. Subjek penelitian ini adalah naskah esai mahasiswa Jurusan Ilmu Hukum, Unissula, semester 1 tahun akademik 2016-107, sedangkan objek penelitian ini adalah kecenderungan pemilihan topik dan kesalahan penulisan judul pada esai mahasiswa Jurusan Ilmu Hukum, Unissula. Metode penelitian yang digunakan adalah metode dokumentasi dari tugas-tugas kuliah mahasiswa. Instrumen yang digunakan untuk mengumpulkan data pada penelitian ini yaitu peneliti itu sendiri sehingga peneliti harus “divalidasi”. Menurut Sugiono (2009, hal 305-306) validasi terhadap peneliti, meliputi pemahaman metode penelitian kualitatif, penguasaan wawasan terhadap bidang yang diteliti, kesiapan peneliti untuk memasuki objek penelitian baik secara akademik maupun logiknya. Dalam penelitian kualitatif, peneliti sebagai human instrument mempunyai fungsi untuk menetapkan fokus penelitian, memilih informan sebagai sumber data, melakukan 
pengumpulan data, menilai kualitas data, analisis data, menafsirkan data, dan membuat simpulan dari hasil temuannya.

Untuk mempermudah pelaksanaan penelitian maka peneliti melaksanakan dengan lima langkah penelitian, yaitu 1) mengumpulkan data, 2) menyusun dan mengolah data, 3) menganalisis data, 4) menafsirkan data, dan 5) dan menarik simpulan. Data dikumpulkan dengan teknik kajian dokumen dari tugas-tugas yang dikumpulkan mahasiswa, yaitu tugas penulisan esai dengan tema bebas. Selanjutnya data yang sudah terkumpul dianalisis dengan model analisis data penelitian kualitatif model Miles dan Huberman yang meliputi teknik reduksi data, penyajian data, dan penarikan data atau verifikasi. Miles dan Huberman (dalam Sugiyono, 2012) menjelaskan bahwa aktivitas dalam analisis data kualitatif dilakukan secara interaktif dan berlangsung secara terus-menerus sampai tuntas, sehingga datanya sudah jenuh. Dengan demikian, proses analisis data dalam penelitian ini berlangsung terus-menerus selama penelitian berlangsung, bahkan sebelum data benar-benar terkumpul. Teknik analisis data tersebut dapat diuraikan sebagai berikut.

1. Reduksi Data

Pada teknik analisis ini peneliti mereduksi data untuk menajamkan, menggolongkan, mengarahkan, membuang yang tidak perlu dan mengorganisasi data kecenderungan pemilahan topik esai dan kesalahan penulisan judul pada naskah esai mahasiswa.

2. Penyajian Data

Setelah data direduksi selanjutnya data disajikan dalam bentuk teks naratif untuk memaparkan atau mendeskripsikan kecenderungan pemilihan topik dan kesalahan penulisan judul pada naskah esai mahasiswa untuk ditarik kesimpulan.

3. Penarikan Simpulan

Tahap terakhir setelah data direduksi dan disajikan adalah penarikan simpulan atau verifikasi. Penarikan simpulan tersebut tentang kecenderungan pemilihan topik dan kesalahan penulisan judul esai pada naskah esai mahasiswa.

\section{HASIL PENELITIAN DAN PEMBAHASAN}

Ada 64 naskah esai mahasiswa yang diteliti dalam penelitian ini. Setelah dilakukan penelitian diperoleh hasil tentang kecenderungan pemilihan topik esai dan kesalahan penulisan judul esai pada naskah esai mahasiswa Jurusan Ilmu Hukum, Unissula.

\section{Kecenderunga Pemilihan Topik Esai}

Pada perkuliahan MKU Bahasa Indonesia mahasiswa diberi tugas untuk menulis esai dengan topik bebas. Topik bebas yang dimaksud adalah dosen sekaligus peneliti hanya 
membatasi 12 topik pilihan yang dapat dipilih mahasiswa sebagai bahan penulisan esai. Dengan kata lain, mahasiswa dibebaskan memilih dan menentukan sendiri topik apa saja dalam menulis esai sesuai dari 12 topik pilihan tersebut. Dari sejumlah 64 naskah esai yang ditulis mahasiswa dapat diklasifikasikan pemilihan topik esai sebagai berikut.

Tabel 1 Jumlah Pemilihan Topik Esai

\begin{tabular}{llc}
\hline No & \multicolumn{1}{c}{ Topik } & Jumlah \\
\hline 1. & Sosial & 18 \\
2. & Politik dan Pemerintahan & 5 \\
3. & Korupsi & 10 \\
4. & Kesehatan & 5 \\
\hline 5. & Pendidikan & 11 \\
6. & Keamanan & 1 \\
\hline 7. & Ekonomi & 2 \\
\hline 8. & Lingkungan & 5 \\
9. & Seni dan Budaya & 0 \\
10. & Hukum & 7 \\
11. & Teknologi & 0 \\
\hline 12. & Olahraga & 0 \\
& Jumlah & 64 \\
\hline
\end{tabular}

Dari data pada tabel tersebut diketahui bahwa mahasiswa yang memilih topik sosial sejumlah 18 mahasiswa, topik politik dan pemerintahan sejumlah 5 mahasiswa, topik korupsi sebanyak 10 mahasiswa, topik kesehatan sebanyak 5 mahasiswa, topik pendidikan sebanyak 11 mahasiswa, topik keamanan sebanyak 1 mahasiswa, topik ekonomi sebanyak 2 mahasiswa, topik lingkungan sebanyak 5 mahasiswa, dan topik tentang hukum sebanyak 7 mahasiswa. Dari 12 topik ternyata ada 3 topik yang tidak dipilih oleh mahasiswa, yaitu topik seni dan budaya, teknologi, dan olahraga. Dengan demikian, dapat disimpulkan bahwa topik sosial yang paling banyak dipilih oleh mahasiswa.

Berdasarkan data pada tabel tersebut maka dapat diketahui jumlah presentase kecenderungan pemilihan topik esai mahasiswa Jurusan Ilmu Hukum, Unissula sebagai berikut. 
Diagram 1 Presentase Kecenderungan Pemilihan Topik Esai

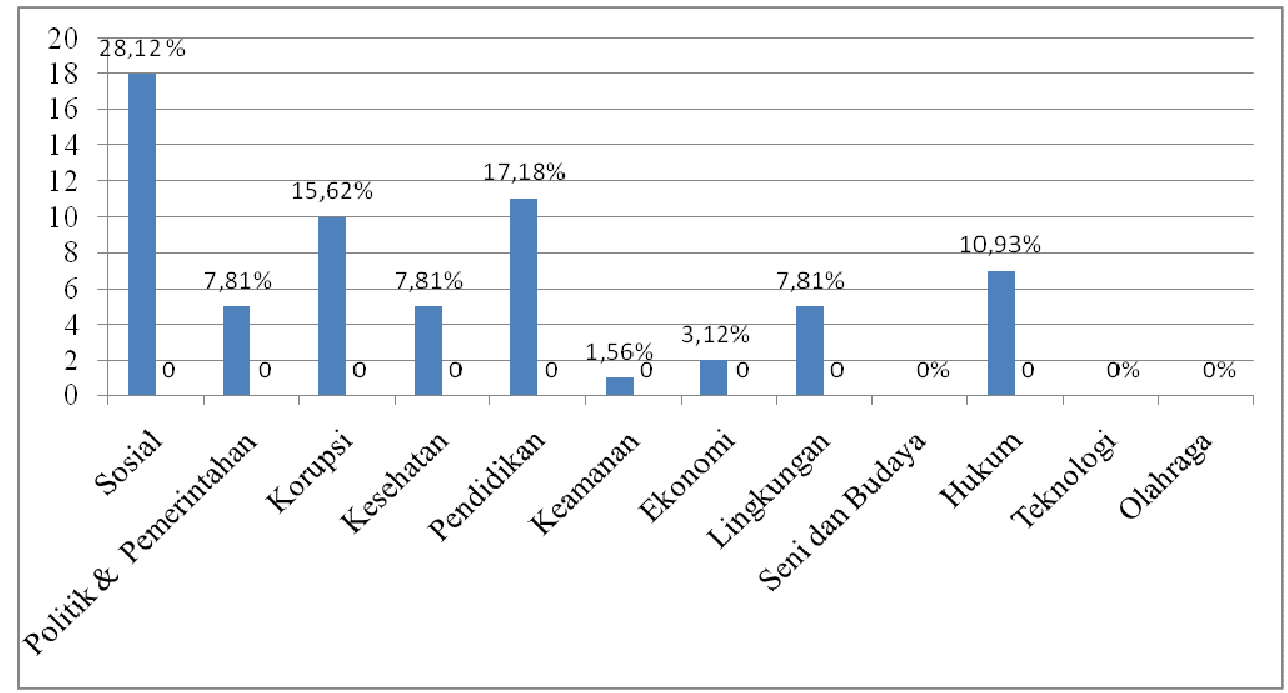

Dari data pada diagram tersebut dapat diketahui bahwa mahasiswa Jurusan Ilmu Hukum, Unissula yang memilih topik sosial sebanyak $28,12 \%$, politik dan pemerintahan $7,81 \%$, korupsi $15,62 \%$, kesehatan $7,81 \%$, pendidikan $17,18 \%$, keamanan $1,56 \%$, ekonomi $3,12 \%$, sosial $28,12 \%$, seni dan budaya $0 \%$, hukum $10,93 \%$, teknologi $0 \%$, olahraga $0 \%$, dan lingkungan $7,81 \%$. Dengan demikian, dapat disimpulkan bahwa topik sosial yang paling banyak dipilih mahasiswa Jurusan Ilmu Hukum, Unissula sebanyak 28,12\%.

Kecenderungan pemilihan topik sosial oleh mahasiswa Jurusan Hukum dipengaruhi oleh tingkat semester. Hal tersebut karena esai yang diteliti dalam penelitian ini ditulis oleh mahasiswa Jurusan Hukum, Unissula semester pertama. Dengan demikian, dapat dikatakan bahwa walaupun mahasiswa Jurusan Ilmu Hukum yang lekat dengan isu-isu masalah hukum, tetapi topik yang cenderung digemari untuk penulisan esai adalah tentang masalah sosial yang terjadi di masyarakat Indonesia. Hal tersebut karena mahasiswa Jurusan Ilmu Hukum semester pertama belum fokus terhadap masalah-masalah hukum. Namun, dapat juga dikatakan bahwa isu-isu sosial yang ada di masyarakat Indonesia rentan sekali dengan masalah hukum.

\section{Kesalahan Penulisan Judul Esai}

Selain memperhatikan pemilihan topik, dalam penulisan esai mahasiswa juga harus memperhatikan penulisan judul. Berdasarkan hasil penelitian dapat diketahui bahwa bentuk atau aspek kesalahan yang dilakukan. Bentuk kesalahan tersebut disajikan pada tabel berikut ini. 
Tabel 2 Aspek Kesalahan Penulisan Judul Esai

\begin{tabular}{clc}
\hline No & \multicolumn{1}{c}{ Aspek } & Jumlah \\
\hline 1. & Huruf capital & 7 \\
2. & Huruf miring & 0 \\
3. & Penulisan kata & 4 \\
4. & Kata hubung & 8 \\
5. & Kata ulang & 0 \\
6. & Kata depan & 0 \\
7. & Interjeksi & 0 \\
8. & Tanda baca & 3 \\
& Jumlah & 22 \\
\hline
\end{tabular}

Dari data pada tabel tersebut diketahui bahwa kesalahan yang dilakukan mahasiswa dalam menulis judul esai, yaitu penulisan huruf kapital, huruf miring, penulisan kata, kata hubung, kata ulang, kata depan, interjeksi, dan penulisan tanda baca. Kesalahan penulisan huruf kapital pada penulisan judul esai dilakukan oleh 7 mahasiswa, kekesalahan penulisan kata dilakukan oleh 4 mahasiswa, kesalahan penulisan kata hubung dilakukan oleh 8 mahasiswa, kesalahan penulisan tanda baca dilakukan oleh 3 mahasiswa. Akan tetapi, kesalahan pada penulisan huruf miring, kata ulang, dan interjeksi tidak dilakukan mahasiswa. Artinya, tidak ada mahasiswa yang melakukan kesalahan tersebut pada penulisan judul esai.

Berdasarkan data pada tabel tersebut maka dapat diketahui jumlah presentase kesalahan penulisan judul esai mahasiswa Jurusan Ilmu Hukum, Unissula sebagai berikut.

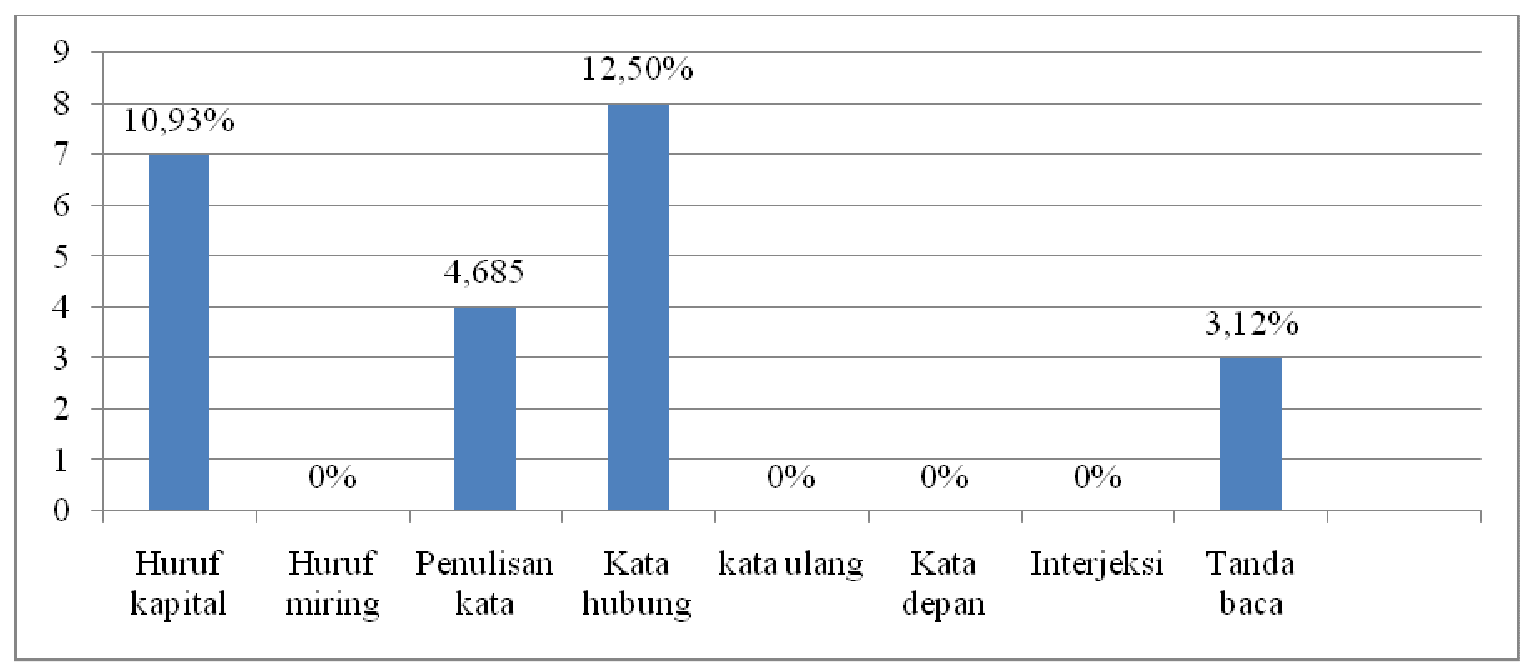

Diagram 2 Presentase Kesalahan Penulisan Judul Esai 
Dari hasil analisis kesalahan penulisan judul esai yang disajikan dalam diagram batang tersebut diketahui bahwa letak kesalahan penulisan judul pada penulisan huruf kapital sebanyak 10,93\%, penulisan kata sebanyak 4,68\%, penulisan kata-kata yang tergolong sebagai partikel, yaitu konjungsi (kata penghubung) sebanyak 12,50\%, dan penulisan tanda baca sebanyak 3,12\%. Pada aspek penulisan huruf miring, kata depan, kata ulang, dan interjeksi (seruan perasaan) sebanyak 0\%. Jumlah total kesalahan terhitung 31,23\% sehingga jumlah penulisan judul yang benar sebanyak 68,77\%. Jadi, kesalahan terbanyak yang dilakukan oleh mahasiswa Jurusan Ilmu Hukum, Unissula yaitu pada penulisan kata hubung. Kata hubung pada judul esai ditulis dengan huruf kapital, padahal seharusnya ditulis dengan huruf kecil. Selain penulisan kata hubung, kesalahan yang banyak dilakukan adalah penulisan huruf kapital. Pada judul esai yang ditulis oleh mahasiswa huruf yang seharusnya ditulis huruf kapital, tetapi ditulis dengan huruf kecil.

Berdasarkan hasil analisis data penelitian diketahui kesalahan penulisan judul esai mahasiswa Jurusan Ilmu Hukum, Unissula sebagai berikut.

\section{Kesalahan Huruf Kapital}

Judul esai yang terdapat kesalahan penggunaan huruf kapital sebagai berikut.

(1) Kisah Indonesia di tangan Jokowi

(2) Dana Pendidikan Tidak tepat Sasaran

(3) Kurangnya lapangan kerja

(4) Hukum, apakah Identik Dengan Keadilan

(5) Indomaret membunuh secara perlahan

(6) Warga Berpendidikan S2 dan S3 masuk dalam kategori Masyarakat Miskin

(7) Anis, Agus, Ahok diminta Solusi dan Gagasan

Pada penulisan judul nomor (1) kesalahan terdapat pada kata tangan karena seharusnya huruf pertama dari kata tangan ditulis kapital. Pada penulisan judul nomor (2) kesalahan terdapat pada penulisan kata tepat karena seharusnya huruf pertama dari kata tepat ditulis kapital. Pada penulisan judul nomor (3) kesalahan terdapat pada penulisan kata lapangan dan kerja karena seharusnya huruf pertama dari kata lapangan dan kerja ditulis kapital. Pada penulisan judul nomor (4) kesalahan terdapat pada penulisan kata apakah dan dengan karena seharusnya huruf pertama dari kata apakah dan dengan ditulis kapital. Pada penulisan judul nomor (5) kesalahan terdapat pada kata membunuh, secara, dan perlahan karena seharusnya huruf pertama dari kata membunuh, secara, dan perlahan ditulis kapital. 
Pada penulisan judul nomor (6) kesalahan terdapat pada kata masuk dan kategori karena seharusnya kata tersebut huruf pertamanya ditulis dengan huruf kapital. Pada penulisan judul nomor (7) kesalahan terdapat pada kata diminta karena seharusnya huruf pertamanya ditulis dengan huruf kapital.

\section{Kesalahan Penulisan Kata}

Judul esai yang terdapat kesalahan penggunaan pemilihan kata sebagai berikut.

(1) Minim Pendidikan dibawah Garis Kemiskinan

(2) Generasi Baru Anti Pungli

(3) Warga Berpendidikan S2 dan S3 masuk dalam kategori Masyarakat Miskin

Pada penulisan judul nomor (1) tersebut letak kesalaha penulisan kata terdapat pada kata dibawah karena seharusnya kata tersebut ditulis terpisah, yaitu di bawah. Partikel diapabila disandingkan dengan kata yang mengacu tempat maka ditulis terpisah. Pada penulisan judul nomor (2) kesalahan terletak pada kata Anti yang seharusnya dirangkai dengat kata Pungli sehingga menjadi Antipungli. Hal tersebut karena kata anti tidak bisa berdiri sendiri sehingga penulsiannya harus dirangkai dengan kata lain yang mengikutinya.

\section{Kesalahan Kata Hubung}

Judul esai yang terdapat kesalahan penulisan kata hubung sebagai berikut.

(1) Buruknya Pelayanan Kesehatan Bagi Warga Miskin

(2) Kriminalitas Dampak Dari Kepadatan Penduduk

(3) Lingkungan Bersih Untuk Indonesia

(4) Hukum, apakah Identik Dengan Keadilan

(5) Budaya Korupsi Di Indonesia

(6) Reformasi Hukum Terhadap Tindak Pidana Narkotika Yang Berbasis Keadilan

(7) Pudarnya Rasa Sopan Santun Siswa Terhadap Guru

(8) Korupsi Bukan Masalah Tapi Budaya

Pada penulisan judul nomor (1) kesalahan penulisan terdapat pada kata Bagi karena seharusnya kata tersebut ditulis dengan huruf kecil semua. Pada penulisan judul nomor (2) kesalahan penulisan terdapat pada kata Dari karena seharusnya kata tersebut ditulis dengan huruf kecil semua. Pada penulisan judul nomor (3) kesalahan penulisan terdapat pada kata Untuk karena seharusnya kata tersebut ditulis dengan huruf kecil semua. Pada penulisan judul nomor (4) kesalahan penulisan terdapat pada kata Dengan karena seharusnya kata tersebut ditulis dengan huruf kecil semua. Pada penulisan judul nomor (5) kesalahan penulisan 
terdapat pada kata $D i$ karena seharusnya kata tersebut ditulis dengan huruf kecil semua. Pada penulisan judul nomor (6) kesalahan terdapat pada kata Terhadap dan Yang karena seharusnya kata tersebut ditulis menggunakan huruf kecil semua. Pada penulisan judul nomor (7) kesalahan terdapat pada kata Terhadap karena seharusnya kata tersebut ditulis menggunakan huruf kecil semua. Pada penulisan judul nomor (8) kesalahan terdapat pada kata Tapi karena seharusnya kata tersebut ditulis menggunakan huruf kecil semua.

\section{Kesalahan Penulisan Tanda Baca}

Judul esai yang terdapat kesalahan penulisan tanda baca sebagai berikut.

(1) Efektifkah Kurikulum 2013

(2) Korupsi Bukan Masalah Tapi Budaya

Pada penulisan judul nomor (1) kesalahan terletak pada tidak adanya tanda tanya (?) pada akhir judul, padahal penulisan judul tersebut menggunakan pola kalimat tanya. Adapun letak kesalahan penulisan tanda baca pada penulisan judul nomor (2) yaitu tidak adanya tanda koma (,) sebelum kata tapi, padahal seharusnya sebelum kata tapi diberi tanda koma.

\section{PENUTUP}

Berdasarkan uraian tersebut maka dapat disimpulkan bahwa pada tugas penulisan esai mahasiswa Jurusan Ilmu Hukum, Unissula lebih cenderung memilih topik sosial dengan jumlah persentase $28,12 \%$. Hal tersebut berarti bahwa meskipun jurusan yang diambil tentang ilmu hukum, tetapi mereka lebih tertarik terhadap isu-isu sosial. Dapat dikatakan juga bahwa isu-isu sosial yang ada di Indonesia rentan sekali dengan masalah hukum. Simpulan yang kedua berkaitan dengan analisis kesalahan penulisan judul esai bahwa letak kesalahan yang paling banyak dilakukan mahasiswa dalam menulis judul esai yaitu penggunaan atau penulisan kata hubung yang ditulis dengan huruf kapital. Kesalahan penggunaan atau penulisan kata hubung mencapai $12,50 \%$. Hal tersebut berarti bahwa tingkat penguasaan materi tentang Tata Bahasa Baku Bahasa Indonesia dan Ejaan Bahasa Indonesia perlu ditingkatkan lagi. Dengan demikian, bagi dosen pengampu mata kuliah Bahasa Indonesia hendaknya lebih aktif lagi dalam mengejarkan mahasiswa tentang Tata Bahasa Baku Bahasa Indonesia dan Ejaan Bahasa Indonesia pada perkuliahan selanjutnya.

\section{DAFTAR PUSTAKA}

Badan Pengembangan dan Pembinaan Bahasa Kemendikbud. (2016). Pedoman Umum Bahasa Indonesia. Jakarta: Kemendikbud. 
Jassin, Hans Bague. (1945). Satra Indonesia Modern dalam Kritik dan Esai. Jakarta: Pustaka Utama.

Kamus Besar Bahasa Indonesia.( 2017). Esai. https://kbbi.web.id/esai. 18 September 2017.

Rahardi, F. (2006). Panduan Lengkap Menulis Artikel, Feature, dan Esai. Jakarta : Kawan Pustaka.

Rampan, Korrie Layun. (2010). Antologi Apresiasi Sastra Indonesia Modern. Yogyakarta: Narasi (Anggota IKAPI).

Sugiyono. (2012). Memahami Penelitian Kualitatif. Bandung: Alfabeta.

Wikipedia Ensiklopedia Bebas. (2017). Esai. https://id.wikipedia.org/wiki/Esai. 18 September 2017. 